\title{
Pemanfaatan Fermentasi Tepung Daun Pepaya (Carica papaya) Menggunakan Rhizopus sp. dalam Pakan terhadap Pertumbuhan Benih Ikan Patin Siam (Pangasianodon hypophthalmus)
}

\author{
Utilization of Papaya Leaf Meal Fermented (Carica Papaya) with Rhizopus sp. in \\ the Dietson Growth of Striped Catfish(Pangasianodon hypophthalmus)
}

\author{
Marni Anita Silalahi ${ }^{1}$, Indra Suharman ${ }^{1}$, Adelina ${ }^{1}$ \\ ${ }^{1}$ Jurusan Budidaya Perairan, Fakultas Perikanan dan Kelautan, Universitas Riau \\ Kampus Bina Widya Jl. HR. Soebrantas Km 12.5, Pekanbaru, 28293 \\ email:marnisilalahi793@gmail.com
}

(Received: 11Januari 2022; Accepted: 28 Februari 2022)

\begin{abstract}
ABSTRAK
Penelitian ini telah dilaksanakan pada November 2019 sampai Januari 2020. Tujuan penelitian ini adalah untuk mengetahui pemanfaatan fermentasi tepung daun pepaya dalam pakan terhadap pertumbuhanikan patin siam. Penelitian ini menggunakan Rancangan Acak Lengkap (RAL) satu faktor dengan 5 perlakuan dan 3 kali ulangan. Ikan dipelihara didalam keramba berukuran $1 \mathrm{~m}^{3}$ dengan padat tebar ikan $25 \mathrm{ekor} / \mathrm{m}^{3}$. Percobaan pemberian pakan dilakukan dengan menggantikan tepung kedelai dengan fermentasi tepung daun pepaya sebanyak $\mathrm{P} 1(0 \%), \mathrm{P} 2(10 \%)$, P3(20\%), P4(30\%), P5(40\%). Bobot ikan yang digunakan dalam penelitian ini yaitu 0,66 $\pm 0,14 \mathrm{~g}$. Hasil penelitian menunjukkan bahwa penggunaan fermentasi tepung daun pepaya berpengaruh nyata $(\mathrm{P}<0,05)$ terhadap pertumbuhan ikan patin siam. Pakan yang mengandung $20 \%$ fermentasi tepung daun pepaya dan $80 \%$ tepung kedelai (P3) memberikan hasil terbaik dengan laju pertumbuhan $(5,52 \%$ /hari), efisiensi pakan $(51,57 \%)$, kecernaan pakan $(77,06 \%)$, retensi protein $(60,40 \%)$. Berdasarkan dari hasil tersebut dapat disimpulkan bahwa fermentasi tepung daun pepaya dapat digunakan sebagai pengganti tepung kedelai didalam pakan ikan patin siam
\end{abstract}

Kata Kunci:Tepung Daun pepaya, Tepung Kedelai, Substitusi, Ikan Patin Siam

\begin{abstract}
This research was conducted from November 2019 to January 2020. The purpose of this research was toknow the use of fermented papaya leaf meal in the dietson the growth of striped catfish.A Completely randomized design (CRD) was used in this experiment, with one factor, five level treatments and three replications. Fish was reared in $1 \mathrm{~m}^{3}$ cage with stocking density $25 / \mathrm{m}^{3}$. The feeding trial was replacing soybean meal with fermented papaya leaf meal applied to P1 $(0 \%), \mathrm{P} 2(10 \%), \mathrm{P} 3(20 \%), \mathrm{P} 4(30 \%), \mathrm{P} 5(40 \%)$. The fish used in this research with $0,66 \pm 0,14 \mathrm{~g}$ of weight. The results of this research showed that fermented papaya leaf meal has a significant effect $(\mathrm{P}<0,05)$ on the growth of striped catfish. Diets that contain $20 \%$ of fermented papaya leaf meal and $80 \%$ of soybean meal (P3) produce the highest specific growth rate (5.52/day), feed efficiency $(51.57 \%)$, and feed digestibility $(77.06 \%)$. Based on this study, it could be concluded that fermented papaya leaf meal can be used as a substitution for soybean meal in diets of stripedcatfish
\end{abstract}

Keyword:Papaya Leaf Meal, Soybean Meal, Substitution, Striped catfish 


\section{Pendahuluan}

Ikan patin merupakan salah satu ikan air tawar yang memiliki peluang ekonomi untuk dibudidayakan karena memiliki harga jual yang tinggi. Karena itulah pengusaha banyak yang berminat untuk membudidayakannya (Bahtiar et al., 2016). Tingginya harga pakan dikarenakan bahan baku yang digunakan masih bergantung dari impor seperti tepung kedelai. Ketergantungan terhadap tepung kedelai dalam pemakaian formulasi pakan, maka perlu dicari alternatif sumber bahan baku lokal yang mudah diperoleh, ketersediaan melimpah, berkesinambungan, dan mempunyai nilai gizi yang cukup tinggi. Salah satu bahan alternatif pengganti yang dapat mensubstitusi tepung kedelai adalah daun pepaya (Carica papaya).

Ditinjau dari kandungan nutrisinya daun pepaya berpotensi untuk dijadikan bahan baku pakan. Onyimoyi dalam Ermawati et al., (2019) menyatakan bahwa daun pepaya merupakan salah satu alternatif bahan pakan sumber protein yang dapat menggantikan bungkil kedelai. Daun pepaya memiliki protein kasar $30,12 \%$; air 10,20\%; serat kasar $5,60 \%$; ekstrak eter 1,20\%; abu $8,45 \%$ dan BETN 44,43\%. Watanabe (1996) menyatakan bahwa jika terlalu banyak serat kasar (>10\%) akan mengakibatkan daya cerna dan penyerapan pakan menurun. Untuk menurunkan kadar serat kasar yang terkandung dalam daun pepaya perlu dilakukan fermentasi.

Fermentasi adalah suatu proses untuk meningkatkan daya cerna bahan karena bahan yang telah difermentasi dapat mengubah substrat bahan tumbuhan yang susah dicerna menjadi protein sel tunggal dari organisme starter seperti Rhyzopus sp sehingga dapat meningkatkan kecernaan bahan (Adelina et al., 2009). Pemakaian Rhizopus sp memberi nilai lebih dengan dihasilkannya senyawa yang dapat berfungsi sebagai atioksidan dan antimikroba (Kurniawan et al., 2019). Rhizopus sp juga meningkatkan kualitas nutrisi, meningkatkan kecernaan dan memudahkan penyerapan mineral dengan mengubahnya menjadi bahan organik (Endrawati dan Kusumaningtyas, 2017).

Berdasarkan penjabaran di atas, penulis tertarik melakukan penelitian tentang fermentasi tepung daun pepaya dalam pakan terhadap pertumbuhan benih ikan patin siam
(P. hypophthalmus) sehingga dapat dipakai sebagai bahan alternatif penyusun pakan ikan

\section{Metode Penelitian}

\subsection{Waktu dan Tempat}

Penelitian ini dilaksanakan pada November 2019- Januari 2020. Persiapan bahan pakan, fermentasi daun pepaya dan pembuatan pakan uji akan dilaksanakan di Laboratorium Nutrisi Ikan Fakultas Perikanan dan Kelautan, Universitas Riau. Pemberian pakan ke ikan uji dilakukan di BAT Rumbai, Pekanbaru. Analisa proksimat pakan akan dilakukan di Laboratorium Nutrisi Ikan IPB.

\subsection{Metode Penelitian}

Metode yang digunakan dalam penelitian adalah metode eksperimen dengan menggunakan Rancangan Acak Lengkap (RAL) dengan 5 taraf faktor dan 3 kali ulangan sehingga diperlukan 15 unit percobaan. Perlakuan yang dilakukan dalam penelitian ini adalah sebagai berikut:

P1 : Fermentasi Tepung Daun Pepaya $0 \%$,

P2 : Fermentasi Tepung Daun Pepaya $10 \%$,

P3 : Fermentasi Tepung Daun Pepaya $20 \%$,

P4 : Fermentasi Tepung Daun Pepaya $30 \%$,

P5 : Fermentasi Tepung Daun Pepaya $40 \%$.

\subsection{Prosedur Penelitian \\ 2.3.1. Persiapan Pakan}

Daun pepaya yang digunakan adalah daun pepaya yang segar, daun pepaya dicuci dengan air mengalir kemudian ditiriskan lalu dipotong kecil-kecil. Setelah itu, daun pepaya dijemur di bawah sinar matahari hingga kering lalu digiling untuk dijadikan tepung. Proses fermentasi tepung daun pepaya dilakukan dengan menggunakan Rhizopus sp. sebagai fermentor. Tepung daun pepaya dikukus selama 15 menit, pengukusan bertujuan untuk mematikan mikroba yang dapat mengggangu proses fermentasi. Selanjutnya ditambahkan Rhizopus sp.yang telah disiapkan dengan dosis $6 \%$ dari berat tepung daun pepaya pada uji pendahuluan, setelah itu diaduk sampai rata. Tepung daun pepaya yang telah dicampur dengan Rhizopus sp. kemudian dimasukkan ke dalam kantong 
plastik tahan panas yang telah dilubangi di beberapa tempat untuk mendapatkan kondisi aerob. Proses fermentasi terjadi 72 jam. Setelah proses fermentasi daun pepaya berhasil (tumbuh jamur pada tepung yang ditandai dengan hifa-hifa jamur berwarna putih, aroma khas fermentasi dan bertekstur lembab) kemudian dikukus kembali selama 15 menit untuk menghentikan proses fermentasi. Setelah kering digiling hingga menjadi tepung dan diayak, maka siap untuk diformulasikan ke dalam pakan. Komposisi tepung biji karet dapat dilihat pada Tabel 1.

Tabel 1. Analisa proksimat tepung daun pepaya (C. papaya) sebelum dan sesudah fermentasi menggunakan Rhizopus sp

\begin{tabular}{cccc}
\hline \multirow{2}{*}{ No } & Komposisi nutrisi & \multicolumn{2}{c}{ Tepung Daun Pepaya } \\
\cline { 3 - 4 } & $(\%$ basah) & Sebelum fermentasi & Sesudah fermentasi \\
\hline 1 & Protein & 22,51 & 24,81 \\
2 & Serat kasar & 12,02 & 6,37 \\
3 & Kadar air & 9,08 & 6,24 \\
\hline
\end{tabular}

Bahan-bahan pakan yang digunakan ditimbang sesuai kebutuhan. Pencampuran bahan dilakukan secara bertahap, mulai dari jumlah yang paling sedikit hingga yang paling banyak sehingga campuran menjadi homogen. Hasil analisis proksimat setiap pakan uji disajikan pada Tabel 2 dan 3.

Tabel 2. Komposisi Pakan Uji pada Setiap Perlakuan

\begin{tabular}{|c|c|c|c|c|c|c|}
\hline \multirow{3}{*}{ Bahan } & \multirow{3}{*}{$\begin{array}{c}\text { Protein } \\
\text { Bahan }\end{array}$} & \multicolumn{5}{|c|}{ Perlakuan } \\
\hline & & P1 (0:100) & P2 (10:90) & P3(20:80) & P4 (30:70) & P5 (40:60) \\
\hline & & $\% \mathrm{~B}$ & $\% \mathrm{~B}$ & $\% B$ & $\% \mathrm{~B}$ & $\% \mathrm{~B}$ \\
\hline T. Ikan & 50 & 41,0 & 42,0 & 43,0 & 44,5 & 45,2 \\
\hline T. DPF & 24,81 & 0,0 & 3,5 & 7,0 & 10,5 & 14,0 \\
\hline T. Kedelai & 35 & 35,0 & 31,5 & 28,0 & 24,5 & 21,0 \\
\hline T.Terigu & 11 & 18,0 & 17,0 & 16,0 & 14,5 & 14,0 \\
\hline Vitamin mix & 0 & 2.0 & 2.0 & 2.0 & 2.0 & 2.0 \\
\hline Mineral mix & 0 & 2.0 & 2.0 & 2.0 & 2.0 & 2.0 \\
\hline Minyak ikan & 0 & 2.0 & 2.0 & 2.0 & 2.0 & 2.0 \\
\hline Jumlah & & 100 & 100 & 100 & 100 & 100 \\
\hline
\end{tabular}

Tabel 3. Analisis Proksimat Pakan

\begin{tabular}{llllll}
\hline Parameter & P1 & P2 & P3 & P4 & P5 \\
\hline Protein & 34,33 & 34,54 & 35,22 & 34,97 & 35,15 \\
Karbohidrat/BETN & 28,11 & 28,18 & 30,62 & 30,69 & 30,36 \\
Lemak & 8,06 & 9,19 & 9,22 & 8,80 & 9,04 \\
Serat Kasar & 11,70 & 8,69 & 5,65 & 5,01 & 4,60 \\
Kadar Air & 8,76 & 9,80 & 9,34 & 9,24 & 9,19 \\
Kadar Abu & 17,04 & 13,85 & 13,11 & 12,04 & 11,66 \\
\hline
\end{tabular}

\subsection{Parameter yang Diukur}

Parameter yang diukur adalah Kecernaan pakan, kecernaan protein, efisiensi pakan, retensi pakan, laju pertumbuhan spesifik, kelulushidupan benih patin siam, kulitas air. Pemberian pakan dilakukan 3 kali sehari yaitu pada pukul 09.00, 13:00 dan 18.00 WIB. Untuk mengukur kemampuan daya cerna ikan digunakan chromic oxide $\left(\mathrm{Cr}_{2} \mathrm{O}_{3}\right)$ yang dicampurkan dalam pakan uji sebanyak $0.5 \%$

\section{Hasil dan Pembahasan}

3.1. Kecernaan Pakan dan Kecernaan Protein

Nilai kecernaan pakan dan kecernaan protein tertinggi terdapat pada perlakuan P3 (20\% fermentasi daun pepaya) sebesar $77,06 \%$ dan $79,45 \%$. Hal ini dikarenakan adanya penambahan Rhizopus sp. pada proses fermentasi yang menghasilkan enzim-enzim pencernaan seperti selulase yang 
mendegradasi selulosa dalam tepung daun pepaya yang dapat mengurangi kadar serat kasar sehingga benih ikan patin siam mampu mencerna pakan yang diberikan dengan baik, dan adanya enzim protease yang memecah protein menjadi asam amino bebas sehingga lebih mudah diserap oleh tubuh ikan.

Tabel 4. Kecernaan Pakan dan Protein (\%) Ikan Patin Siam pada Setiap Perlakuan Selama Penelitian

\begin{tabular}{ccc}
\hline Perlakuan (\%TDPF:\%TK) & Kecernaan pakan (\%) & Kecernaan Protein(\%) \\
\hline P1 (0: 100) & 75,73 & 76,19 \\
P2 (10:90) & 76,64 & 79,11 \\
P3 (20: 80) & 77,06 & 79,45 \\
P4 (30: 70) & 75,12 & 78,50 \\
P5 (40: 60) & 75,85 & 78,15 \\
\hline
\end{tabular}

Keterangan : TK $=$ Tepung Kedelai, TDPF $=$ Tepung Daun Pepaya Fermentasi

Menurut Hepher (1990) kecernaan pakan dipengaruhi oleh keberadaan enzim dalam saluran pencernaan ikan, tingkat aktivitas enzim-enzim pencernaan dan lama kontak pakan yang dimakan dengan enzim pencernaan. Afrianto dan Liviawaty (2005) menambahkan bahwa pada prinsipnya nilai kecernaan ikan terhadap pakan buatan yang diberikan tergantung pada tingkat penerimaan ikan dan enzim yang dimilikinya.

Rendahnya kecernaan pakan dan protein disebabkan oleh rendahnya kemampuan ikan dalam mencerna pakan. Adapun kecernaan pakan yang paling rendah ada pada P4 (30\% fermentasi daun pepaya) yaitu $75,12 \%$. Berdasarkan hasil analisa proksimat, pakan $\mathrm{P} 4$ (30\% fermentasi daun pepaya) memiliki kandungan karbohidrat lebih tinggi yaitu 30,69 jika dibandingkan dengan pakan lainnya. Hal itu menyebabkan kecernaan pakan dan protein menjadi rendah dan sulit dimanfaatkan ikan. Menurut Murtidjo (2001) karbohidrat dan serat kasar berlebihan dapat menyebabkan kecernaan dan konsumsi pakan menurun. Namun dalam jumlah tertentu serat kasar dibutuhkan antara lain untuk membentuk gumpalan kotoran agar mudah dikeluarkan dari usus.

\subsection{Efisiensi Pakan}

Efisiensi pakan merupakan kemampuan ikan untuk memanfaatkan pakan secara optimal. Data rata-rata efisiensi pakan dapat dilihat pada Tabel 5

Tabel 5. Efisiensi pakan (\%) Ikan Patin Siam ( P. hypophthalmus) pada Setiap Perlakuan Selama Penelitian

\begin{tabular}{llllll}
\hline \multirow{2}{*}{ Ulangan } & \multicolumn{5}{c}{ Perlakuan ( TDPF\%: TK\%) } \\
\cline { 2 - 6 } & P1 (0:100) & P2 (10:90) & P3 (20:80) & P4 (30:70) & P5 (40:60) \\
\hline 1 & 46,90 & 48,60 & 50,74 & 48,72 & 48,54 \\
2 & 44,34 & 44,32 & 50,97 & 48,34 & 45,16 \\
3 & 45,49 & 48,27 & 55,69 & 48,14 & 47,68 \\
\hline Jumlah & 136,73 & 141,19 & 157,40 & 145,20 & 141,37 \\
\hline Rata-rata & $45,57 \pm 1,28^{\mathrm{a}}$ & $47,06 \pm 2,38^{\mathrm{a}}$ & $52,46 \pm 2,79^{\mathrm{b}}$ & $48,40 \pm 0,29^{\mathrm{a}}$ & $47,12 \pm 1,75^{\mathrm{a}}$ \\
\hline
\end{tabular}

Keterangan : TK= Tepung Kedelai, TDPF $=$ Tepung Daun Pepaya Fermentasi; Huruf yang berbeda pada baris yang sama menunjukkan adanya perbedaan yang nyata antar perlakuan $(\mathrm{P}<0,05)$.

Berdasarkan Tabel 5 menunjukkan bahwa efisiensi pakan tertinggi selama penelitian terdapat pada perlakuan P3 $(20 \%$ tepung daun pepaya fermentasi) yaitu sebesar $52,46 \%$, hal ini disebabkan karena pakan dalam perlakuan $\mathrm{P} 3$ mengandung tepung daun pepaya fermentasi sehingga dapat dimanfaatkan dan dicerna dengan baik oleh ikan patin siam. Adelina et al., (2009) menyatakan bahwa pakan yang difermentasi lebih mudah dicerna dan diserap oleh usus sehingga lebih efisien dimanfaatkan. Hal ini sesuai dengan yang disampaikan oleh NRC (1993) bahwa efisiensi pakan berhubungan erat dengan kesukaan ikan akan pakan yang 
diberikan, selain itu dipengaruhi oleh kemampuan ikan dalam mencerna pakan.

Efisiensi pakan terendah terdapat pada perlakuan P1 ( $0 \%$ fermentasi tepung daun pepaya) yaitu $45,57 \%$, hal tersebut diduga karena beberapa faktor antara lain tingkat kesukaan ikan terhadap pakan yang diberikan, dan tidak adanya proses fermentasi di dalam pakan yang menyebabkan nilai kecernaan menjadi rendah dan kemampuan ikan dalam memanfaatkan pakan yang diberikan menjadi rendah juga. Widyanti (2009); Raudah et al. (2018) menyatakan bahwa pakan yang tanpa campuran enzim memiliki nilai efisiensi yang paling rendah, semakin kecil nilai efisiensi pakan maka ikan tidak dapat efisien dalam memanfaatkan pakan atau dapat dikatakan boros dalam memanfaatkan pakan. Dari hasil uji analisi variansi (ANAVA) menunjukkan adanya pengaruh penggunaan fermentasi tepung daun pepaya dalam pakan ikan patin siam terhadap efisiensi pakan $(\mathrm{P}<0,05)$. Hasil uji lanjut Student Newman Keuls menunjukkan bahwa efisiensi pakan P3 berbeda nyata dengan semua perlakuan.

\subsection{Retensi Protein}

Retensi protein merupakan presentase perbandingan antara jumlah protein yang disimpan ikan dalam tubuh dengan jumlah protein yang diberikan pada pakan. Rata-rata retensi protein dari semua perlakuan yaitu berkisar 47,38-60,46\%. Retensi protein tertinggi terdapat pada P3 (20\% tepung daun pepaya fermentasi) yaitu $60,46 \%$ dan terendah terdapat pada perlakuan P1 $(0 \%$ tepung daun pepaya fermentasi) yaitu $47,38 \%$. Tingginya retensi protein ada P3 disebabkan karena kadar protein yang terkandung dalam pakan dapat dimanfaatkan secara baik oleh benih ikan patin siam. Meningkatnya protein dalam tubuh ikan berarti ikan mampu memanfaatkan protein pakan yang diberikan secara optimal untuk kebutuhan tubuh seperti metabolisme dan untuk pertambahan protein tubuh ikan, hal ini sesuai dengan Sukran (2018) yang menyatakan bahwa nilai retensi protein dipengaruhi oleh kemampuan ikan dalam memanfaatkan protein secar aoptimal yang diperoleh dari protein pakan.Nilai rata-rata retensi protein ikan patin siam selama penelitian dapat dilihat pada Tabel 6 .

Tabel 6. Retensi Protein (\%) Ikan Patin Siam Selama Penelitian

\begin{tabular}{cccccc}
\hline Ulangan & \multicolumn{5}{c}{ Perlakuan ( TDPF\%: TK\%) } \\
\cline { 2 - 6 } & P1 (0:100) & P2 (10:90) & P3 (20:80) & P4 (30:70) & P5 (40:60) \\
\hline 1 & 48,07 & 53,78 & 57,32 & 51,91 & 54,75 \\
2 & 47,39 & 45,03 & 59,31 & 54,74 & 48,80 \\
3 & 46,70 & 53,34 & 64,76 & 52,86 & 53,71 \\
\hline Jumlah & 142,16 & 152,14 & 181,39 & 159,51 & 157,26 \\
\hline Rata-rata & $47,38 \pm 0,68^{\text {a }}$ & $50,71 \pm 4,92^{\text {a }}$ & $60,46 \pm 3,85^{\text {b }}$ & $53,17 \pm 3,17^{\text {a }}$ & $52,42 \pm 3,17^{\text {a }}$ \\
\hline
\end{tabular}

Keterangan : Huruf yang berbeda pada baris yang sama menunjukkan adanya perbedaan yang nyata antar perlakuan $(\mathrm{P}<0,05)$.

Pada perlakuan P1 (0\% tepung daun pepaya fermentasi) memiliki nilai retensi protein terendah yaitu $47,38 \%$. Hal ini diduga karena tidak ada proses fermentasi, sehingga menyebabkan pakan pada perlakuan ini sulit dicerna dan nutrisi dalam pakan tidak terserap dengan baik untuk menambah protein tubuh. Dari hasil uji analisi variansi (ANAVA) menunjukkan adanya pengaruh penggunaan fermentasi tepung daun pepaya dalam pakan ikan patin siam terhadap retensi protein $(\mathrm{P}<0,05)$. Hasil uji lanjut Student Newman Keuls menunjukkan bahwa retensi protein $\mathrm{P} 3$ berbeda nyata dengan semua perlakuan.

\subsection{Laju Pertumbuhan Ikan Patin Siam}

Hasil pengamatan terhadap benih ikan patin siam yang dipelihara selama 56 hari berkisar antara 0,65-14,83 g.Pada perlakuan P3 (20\% tepung daun pepaya fermentasi) menunjukkan pertumbuhan bobot tertinggi yaitu sebesar 14,83 g, hal ini disebabkan karena pakan dengan penambahan tepung daun pepaya fermentasi lebih disukai ikan dan mampu dimanfaaatkan untuk pertumbuhan benih ikan patin siam. Sementara pertumbuhan bobot terendah terdapat pada perlakuan P1 (kontrol) sebesar 10,13 g, hal ini disebabkan karena pakan P1 memliki serat kasar yang cukup tinggi sehingga menyebabkan ikan kurang mampu mencerna 
dengan baik. Hal ini sesuai dengan pendapat Mudjiman (1984), bahwa pemberian serat kasar dalam pakan sebaiknya diperhatikan, karena serat kasar dalam jumlah berlebihan dapat menyebabkan gangguan dalam proses penyerapan pakan dalam usus halus.

Rata-rata laju pertumbuhan spesifik ikan uji yang dipelihara selama penelitian berkisar $4,89-5,52 \%$. Rata-rata laju pertumbuhan spesifik tertinggi terdapat pada P3 (20\% tepung daun pepaya fermentasi) yaitu sebesar $5,52 \%$, hal ini dikarenakan adanya aktifitas enzim pada proses fermentasi tepung daun pepaya oleh kapang Rhizopus sp. sehingga menyediakan nutrisi yang lebih sederhana dan lebih efisien, sehingga efisiensi pakan meningkat dan mampu dimanfaatkan ikan dengan baik untuk meningkatkan protein tubuh ikan yang dibutuhkan untuk pertumbuhan ikan. Hal ini sesuai dengan pernyataan Adelina et al. (2009) menyatakan fermentasi merupakan suatu proses untuk meningkatkan daya cerna karena bahan yang telah difermentasi dapat mengubah substrat bahan tumbuhan yang susah dicerna menjadi mudah dicerna dengan bantuan enzim-enzim pencernaan.

Untuk lebih jelasnya pertambahan bobot rata-rata benih ikan patin siam pada setiap perlakuan dapat dilihat pada Gambar 1 .

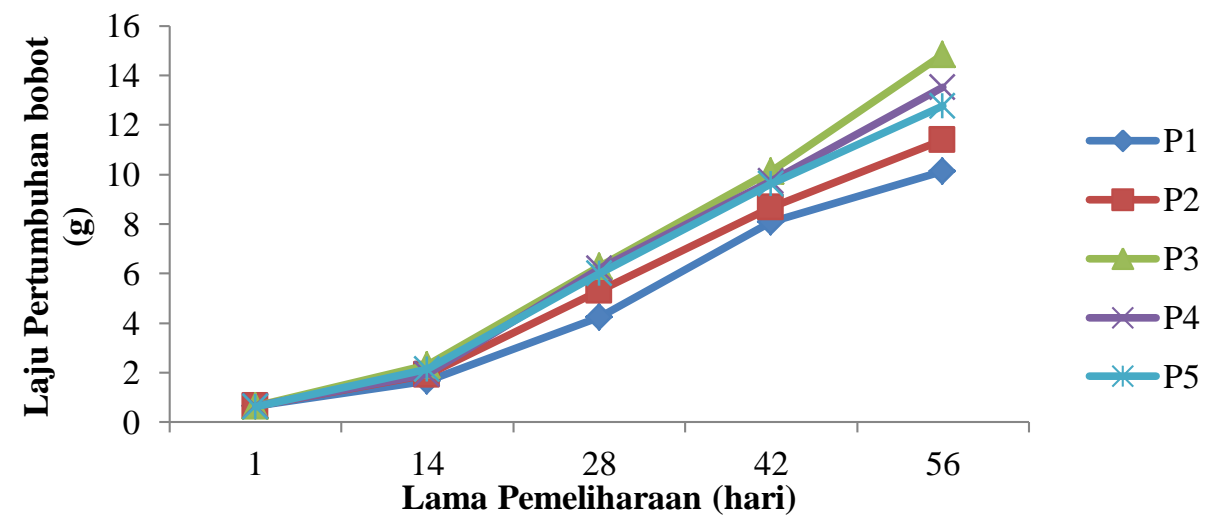

Gambar 1. Perubahan Bobot Individu Ikan Patin Siam Selama Penelitian

Rendahnya nilai laju pertumbuhan spesifik pada perlakuan P1 (0\% tepung daun pepaya fermentasi) diduga karena tidak adanya penambahan tepung daun pepaya fermentasi pada pakan yang diberi menyebabkan kandungan nutrisi yang ada pada pakan lebih sedikit yang dimanfaatkan. Dari hasil uji analisi variansi (ANAVA) menunjukkan adanya pengaruh penggunaan fermentasi tepung daun pepaya dalam pakan ikan patin siam terhadap laju pertumbuhan spesifik $(\mathrm{P}<0,05)$. Hasil uji lanjut Student Newman Keuls menunjukkan bahwa laju pertumbuhan spesifik, P3 tidak berbeda nyata dengan P4 dan P5 tetapi berbeda nyata dengan perlakuan lain. Selanjutnya untuk melihat pertumbuhan ikan patin siam dapat dilihat melalui perhitungan laju pertumbuhan spesifik pada Tabel 7

Tabel 7. Laju Pertumbuhan Spesifik (\%) Individu Ikan Patin Siam (P. hypophthalmus)

\begin{tabular}{llllll}
\hline \multirow{2}{*}{ Ulangan } & \multicolumn{5}{c}{ Perlakuan ( TDPF\%: TK\%) } \\
\cline { 2 - 6 } & P1 (0:100) & P2 (10:90) & P3 (20:80) & P4 (30:70) & P5 (40:60) \\
\hline 1 & 4,96 & 5,13 & 5,39 & 5,36 & 5,33 \\
2 & 4,95 & 4,96 & 5,56 & 5,35 & 5,21 \\
3 & 4,78 & 5,21 & 5,61 & 5,45 & 5,44 \\
\hline Jumlah & 14,69 & 15,31 & 16,56 & 16,15 & 15,98 \\
\hline Rata-rata & $4,89 \pm 0,10^{\text {a }}$ & $5,10 \pm 0,12^{\mathrm{b}}$ & $5,52 \pm 0,11^{\mathrm{c}}$ & $5,38 \pm 0,55^{\mathrm{c}}$ & $5,32 \pm 0,11^{\mathrm{c}}$ \\
\hline
\end{tabular}

Keterangan : Huruf yang berbeda pada baris yang sama menunjukkan adanya perbedaan yang nyata antar perlakuan $(\mathrm{P}<0,05)$.

\subsection{Laju Pertumbuhan Ikan Patin Siam}

Kelulushidupan ikan patin siam berkisar 96-99\%. Tingginya angka kelulushidupan ikan pada setiap perlakuan menunjukan bahwa pakan dengan penambahan fermentasi daun pepaya dapat dimanfaatkan dengan baik oleh 
ikan patin siam untuk menjaga kelangsungan hidupnya. Kematian ikan disebabkan karena kurang baiknya penanganan ikan pada saat penimbangan selama sampling. Data hasil perhitungan kelulushidupan benih ikan patin siam dapat dilihat pada Tabel 8.

Tabel 8. Kelulushidupan (\%) Benih Ikan Patin Siam (P. hypophthalmus) Selama Penelitian

\begin{tabular}{cccccc}
\hline & \multicolumn{5}{c}{ Perlakuan (\% TDPF: \% TK) } \\
\cline { 2 - 6 } Ulangan & P1(0:100) & P2(10:90) & P3(20:80) & P4(30:70) & P5(40:60) \\
\hline 1 & 96 & 100 & 96 & 92 & 100 \\
2 & 100 & 92 & 100 & 100 & 96 \\
3 & 96 & 100 & 100 & 96 & 100 \\
\hline Jumlah & 292 & 292 & 296 & 288 & 296 \\
\hline Rata-rata & 97 & 97 & 99 & 96 & 99 \\
\hline
\end{tabular}

\subsection{Biaya Pakan}

Biaya pembuatan pakan termurah ada pada P5 (40\% tepung daun pepaya fermentasi dan $60 \%$ tepung kedelai) yaitu Rp. $9.202 / \mathrm{Kg}$. Hal ini dikarenakan pada perlakuan P5 lebih sedikit menggunakan tepung kedelai dalam pembuatan pakan dibandingkan dengan perlakuan lainnya. Lebih jelas dapat dilihat pada Tabel 9.

Tabel 9. Rincian Biaya Pembuatan Pakan

\begin{tabular}{cc}
\hline Perlakuan & Biaya $(\mathrm{RP} / \mathrm{Kg})$ \\
(\%TDF:\%TK) & \\
\hline P1 $(0: 100)$ & 10078 \\
P2 $(10: 90)$ & 9853 \\
P3 $(20: 80)$ & 9628 \\
P4 $(30: 70)$ & 9430 \\
P5 $(40: 60)$ & 9202 \\
\hline
\end{tabular}

\section{Kesimpulan dan Saran}

Substitusi fermentasi tepung daun pepaya menggunakan Rhizopus sp. dalam pakan buatan dapat meningkatkan pertumbuhan benih ikan patin siam. Penggunaan fermentasi tepung daun pepaya sebanyak 20\% (P3) memberi nilai terbaik terhadap efisiensi pakan $(51,57 \%)$, retensi protein $(60,40 \%)$, laju pertumbuhan spesifik $(5,52 \%)$ dan dapat meningkatkan kecernaan pakan $(77,06 \%)$ dan kecernaan protein $(79,45 \%)$ pada benih ikan patin siam.

Penulis menyarankan agar adanya penelitian lanjutan tentang fermentasi tepung daun pepaya dengan tingkat penggunaan yang sama pada hewan uji yang berbeda sehingga diharapkan dapat mengoptimalkan penggunaan daun pepaya dalam pakan.

\section{Daftar Pustaka}

Adelina., I. Boer dan I. Suharman. (2009). Pakan Ikan Budidaya dan Analisis
Formulasi. Unri Press. Pekanbaru. 102 hlm.

Afrianto, E. dan E. Liviawaty. (2005). Pakan Ikan. Yogyakarta: Kanisius

Bahtiar A., B. Supeno dan M.A.P Negara. (2016). Rancang Bangun Pengontrol Suhu dan Kekeruhan Air Kolam Ikan Patin Berbasis Fuzzy Logic. Jurnal Arus Elektro Indonesia, 2(3): 7-12.

Endrawati D., dan E. Kusumaningtyas. (2017). Beberapa Fungsi Rhizopus sp dalam Meningkatkan Nilai Nutrisi Bahan Pakan. Wartazoa, 27(2): 81-88.

Ermawati B., Sugiharto, dan H.I. Wahyuni. (2019). Bobot Relatif Organ Pencernaan dan Organ Limfoid Ayam Kampung Super yang diberi Pakan Fermentasi Daun Biji Pepaya. Jurnal Peternakan.1(2).

Hepher, B. (1990). Nutrition of pond fishes.New York: Cambridge, Cambridge University Press.

Kurniawan, W., I. Suharman, dan Adelina. (2019). The Effect of Fermented Moringa oliefera Leaf Meal in The Formulated Diets of Gouramy (Osphronemus gouramy). Jurnal Perikanan dan Kelautan, 24(1): 1-9

Mudjiman, A. (1984). Makanan Ikan. Penebar Swadaya : Jakarta. $190 \mathrm{hlm}$

NRC. (1993). Nutrient Requirements of Fish. National Academy Press. Washington D.C. USA.

Raudah, P., I. Suharman, dan H. Alawi. (2018). Utilization of Leucaena Leaves Meal Gung (Leucaena leucocephala) Fermented by Aspergillus niger as Subtitution of Soybean Meal in The Diets on The Growth og Thai Cat Fish (Pangasius hypophthalmus). Jurnal Perikanan dan Kelautan, 23(2): 1-8 
Sudjatinah, C.H., Wibowo dan P. Widyaningrum. (2005). Pengaruh pemberian ekstrak daun pepaya terhadap tampilan produksi ayam broiler. J. Indon. Trop. Animm. Agric., 30:224-228

Sukran, S.H., I. Suharman, dan Adelina. (2021). Pengaruh Tepung Daun Lemna (Lemna minor) Fermentasi pada Pakan Formulasi terhadap Pertumbuhan Gurami (Osphronemus gouramy). Jurnal Ilmu Perairan (Aquatic Science), 9(2): 86-93
Watanabe, T. (1988). Fish nutrition and mariculture. JICA. The General Aquaculture Course. Dept of Agriculture Bioscience. Tokyo University

Widyanti, W. (2009). Kinerja Pertumbuhan Ikan Nila Oreochromis niloticus yang diberi Berbagai Dosis Enzim Cairan Rumen Pada Pakan Berbasis Daun Lamtoro gung Leucaena leucocephala. Skripsi. Fakultas Perikanan dan Ilmu Kelautan. Institut Pertanian Bogor. Bogor. 68 hlm. 